Images in...

\title{
An unusual presentation of abdominal distension
}

\author{
Dustin G Williams, ${ }^{1}$ Erik P Castle, ${ }^{2}$ Kristi L Harold ${ }^{1}$ \\ 1Department of General Surgery, Mayo Clinic Arizona, Phoenix, Arizona, USA; \\ ${ }^{2}$ Department of Urology, Mayo Clinic Arizona, Phoenix, Arizona, USA
}

Correspondence to Dustin G Williams, williams.dustin@mayo.edu

\section{DESCRIPTION}

A middle-aged man presented with increased abdominal girth over 6-9 months, associated with pain in the right upper quadrant and flanks. History was significant for a non-seminomatous testicular cancer in his teens with left orchiectomy, aortic node dissection and 1 week of chemotherapy. On examination, the abdomen was grossly distended and non-tender, with positive fluid wave and dullness to percussion. At an outside facility, laboratory values were within normal limits, including tumour markers, and ultrasound demonstrated what was believed to be a large amount of ascites and possible pancreatic mass. CT clarified this as a slightly complex-appearing cystic mass filling the entire abdomen and pelvis. He underwent an aspiration of 5 litres, and cytology of the fluid demonstrated spermatocytes. At our institution, MRI showed a markedly distended urinary bladder, measuring $29 \times 26 \times$ $12 \mathrm{~cm}$ (figures 1 and 2). At cystoscopy, 7 litres of urine was drained and he has since initiated self-intermittent catheterisation. Urodynamic study with cystoscopy at 3-month follow-up showed an atonic and very floppy trabeculated bladder without any prostatic obstruction. A diagnosis of idiopathic neurogenic bladder has been made.

Neurogenic bladder can be caused by any number of conditions that disrupt the coordinated interaction of motor and sensory inputs of both the autonomic and somatic

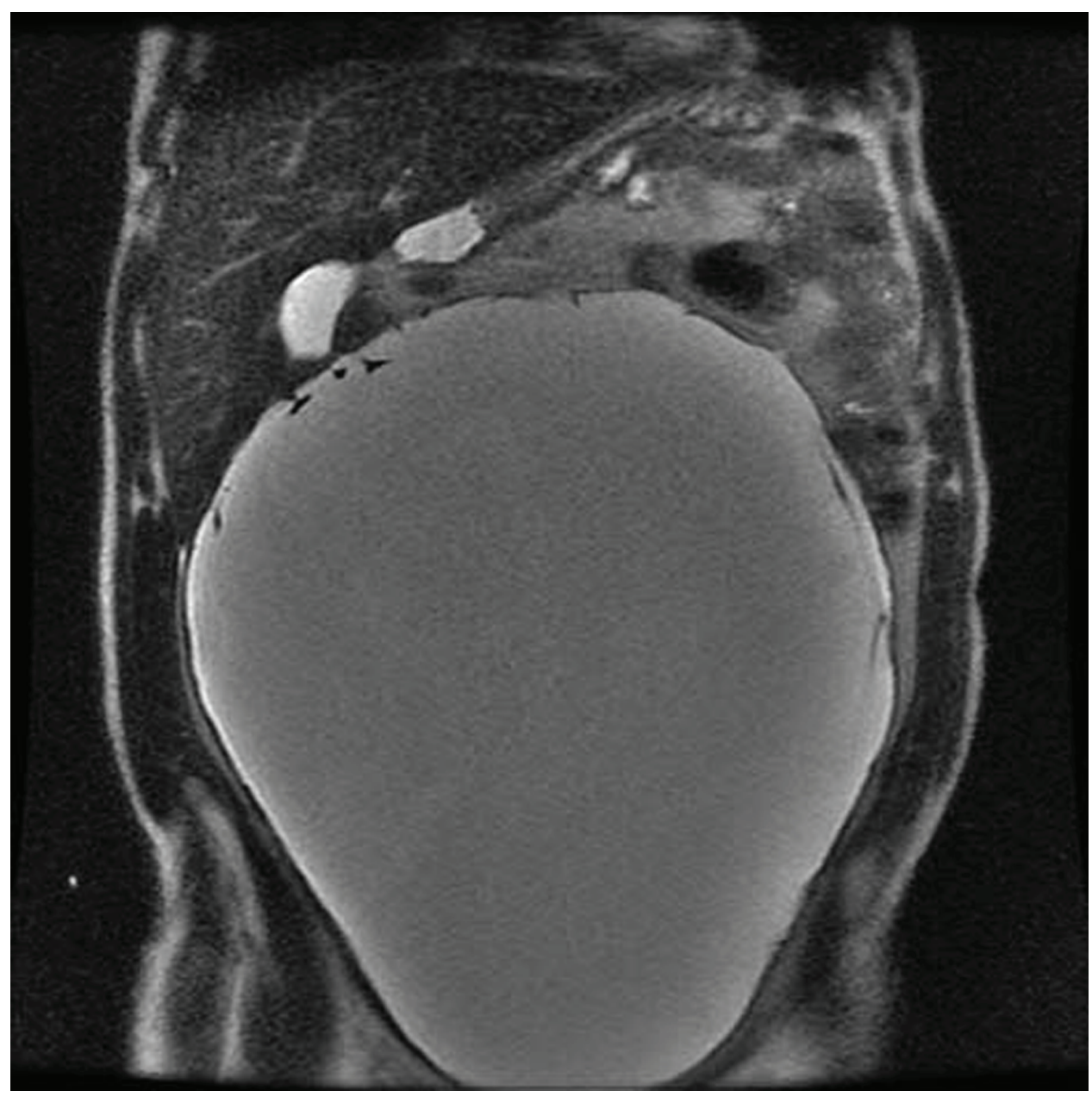

Figure 1 MRI coronal view showing the urinary bladder occupying the entire abdominal cavity. 


\section{BMJ Case Reports}

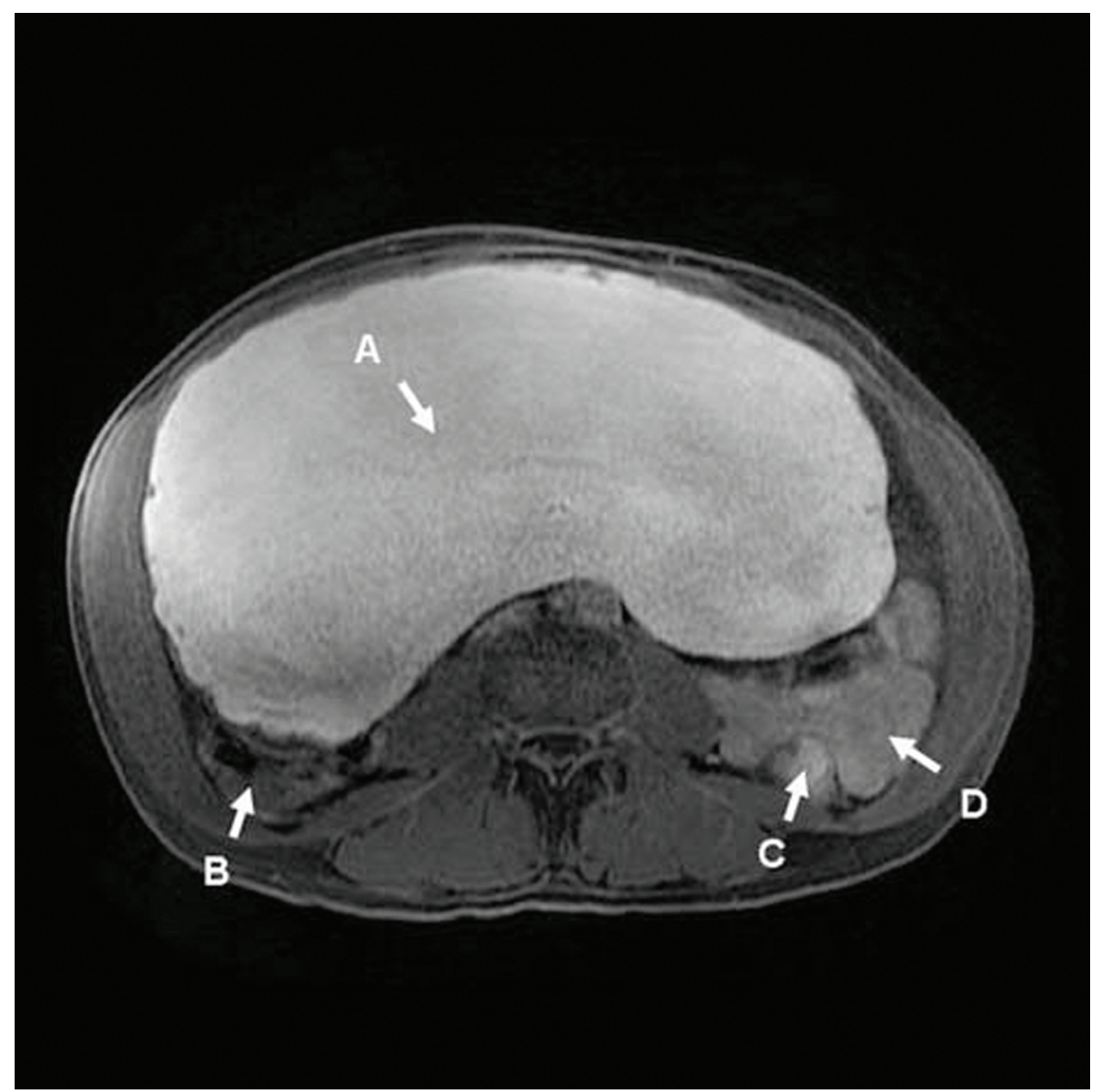

Figure $2 \mathrm{MRI}$ transverse view at the level of $\mathrm{L} 3$ showing $(\mathrm{A})$ the urinary bladder compacting intra-abdominal structures, (B) the ascending colon, (C) the descending colon and (D) compressed small bowel.

nervous systems. Causes include multiple sclerosis, spinal cord injury, diabetes mellitus, Parkinson's disease, amyotrophic lateral sclerosis or iatrogenic injury from spinal or pelvic surgery. ${ }^{1}$ Of note, chemotherapy with vincristine has been known to cause bladder neuropathy due to neurotoxicity and could have played a role in our patient, although this cause is extremely rare and unlikely given the delayed onset of bladder dysfunction from time of chemotherapy. ${ }^{2}$ In addition, our patient's previous chemotherapeutic regimen is remote and unclear.
Competing interests None.

Patient consent Not obtained.

\section{REFERENCES}

1. Tanagho EA, McAninch JW. Smith's General Urology. 17th edition. New York: The McGraw-Hill Companies 2008.

2. Wheeler JS Jr, Siroky MB, Bell R, et al. Vincristine-induced bladder neuropathy. J Urol 1983;130:342-3. 
This pdf has been created automatically from the final edited text and images.

Copyright 2011 BMJ Publishing Group. All rights reserved. For permission to reuse any of this content visit http://group.bmj.com/group/rights-licensing/permissions.

BMJ Case Report Fellows may re-use this article for personal use and teaching without any further permission.

Please cite this article as follows (you will need to access the article online to obtain the date of publication).

Williams DG, Castle EP, Harold KL. An unusual presentation of abdominal distension. BMJ Case Reports 2011;10.1136/bcr.10.2010.3397, date of publication

Become a Fellow of BMJ Case Reports today and you can:

- Submit as many cases as you like

- Enjoy fast sympathetic peer review and rapid publication of accepted articles

Access all the published articles

- Re-use any of the published material for personal use and teaching without further permission

For information on Institutional Fellowships contact consortiasales@bmjgroup.com

Visit casereports.bmj.com for more articles like this and to become a Fellow 